\title{
Business Credit, Household Credit and Economic Performance in Malaysia: A Quantile Regression Approach
}

\author{
Siong Hook Law ${ }^{\mathrm{a}}$ \\ M.N.A. Naseem ${ }^{b}$ \\ Anitha Roslan ${ }^{c}$ \\ Universiti Putra Malaysia \\ Nirvikar Singh ${ }^{\mathrm{d}}$ \\ University of California, Santa Cruz
}

\begin{abstract}
This study examines the effects of business (enterprise) credit and household credit on economic performance in Malaysia. The World Bank's Doing Business report ranked Malaysia at number one among developing countries in terms of ease of getting credit in the six consecutive years since 2008. The analysis is based on quantile regression estimations, using quarterly time series datasets from 1999: Q4 to 2019: Q4. The empirical findings reveal that business credit is positively associated with economic performance whereas household credit is an insignificant determinant of economic performance. We also consider the interaction between credit and institutional quality, an emerging key fundamental variable that determines economic performance. The results demonstrate that only the interaction term between business credit and institutions is statistically significant. In short, business credit outperforms household credit in promoting economic performance in Malaysia. The empirical findings are robust to alternative control variables and quantile regression estimation techniques.
\end{abstract}

Keywords: Business credit, household credit, economic performance, quantile regression JEL classification: G29, 011, 043

\section{Introduction}

The World Bank's Doing Business (2014) report ranked Malaysia at number one across the developing countries in terms of ease of getting credit in the six years since 2008. The Malaysian domestic credit to the private sector was last measured at $121 \%$ of

a School of Business and Economics, Universiti Putra Malaysia, 43400 UPM Serdang Selangor, Malaysia. Email: lawsh@upm.edu.my (Corresponding author)

b School of Business and Economics, Universiti Putra Malaysia, 43400 UPM Serdang Selangor, Malaysia. Email: naseemniaz@upm.edu.my

c School of Business and Economics, Universiti Putra Malaysia, 43400 UPM Serdang Selangor, Malaysia. Email: anitharoslan@upm.edu.my

d Department of Economics, University of California, Santa Cruz, Santa Cruz, CA 95064, USA. Email: boxjenk@ucsc.edu

* We are grateful for the financial support from the Group Putra Grant (GP-IPB 2015, vote number 9440902, UPM). 
gross domestic product (GDP) in 2019 (World Development Indicators), one of the highest among developing countries. The boom of credit during these periods was driven by high demand of enterprises or businesses for investment and households for consumption. Are credit booms in Malaysia a major concern? The finance growth theory postulates a positive long-run relationship between private sector credit (a measure of financial development) and economic growth, but the roles of business credit and household credit in influencing economic performance remain an important issue to be addressed. The question of whether a country that is easy to obtain credit can help to promote economic growth, has been subjected to ambiguous findings in the existing literature (Hung \& Cothren, 2002). For example, some work indicates that business credit positively affects economic growth, while household credit has a negative effect on economic growth (Beck et al., 2012; Sassi \& Gasmi, 2014). Aghion et al. (2010) also demonstrated that business credit can lead to higher economic growth. Nevertheless, another study by Jappelli and Pagano (1994) found that household credit has an adverse impact on economic growth via decreasing the saving rate. Another strand of the literature highlights that household credit caused financial instability (Buyukkarabacak \& Valev, 2010).

Researchers at the Bank for International Settlement (BIS) and the World Bank (2016) have suggested that the level of credit available to the private sector is good for growth, but only up to a point (90-100\% of gross domestic product, GDP), after which it harms economic growth (Arcand et al., 2012; Cecchetti \& Kharroubi, 2012; Law \& Singh, 2014). After passing the turning point, the role of private sector credit provided

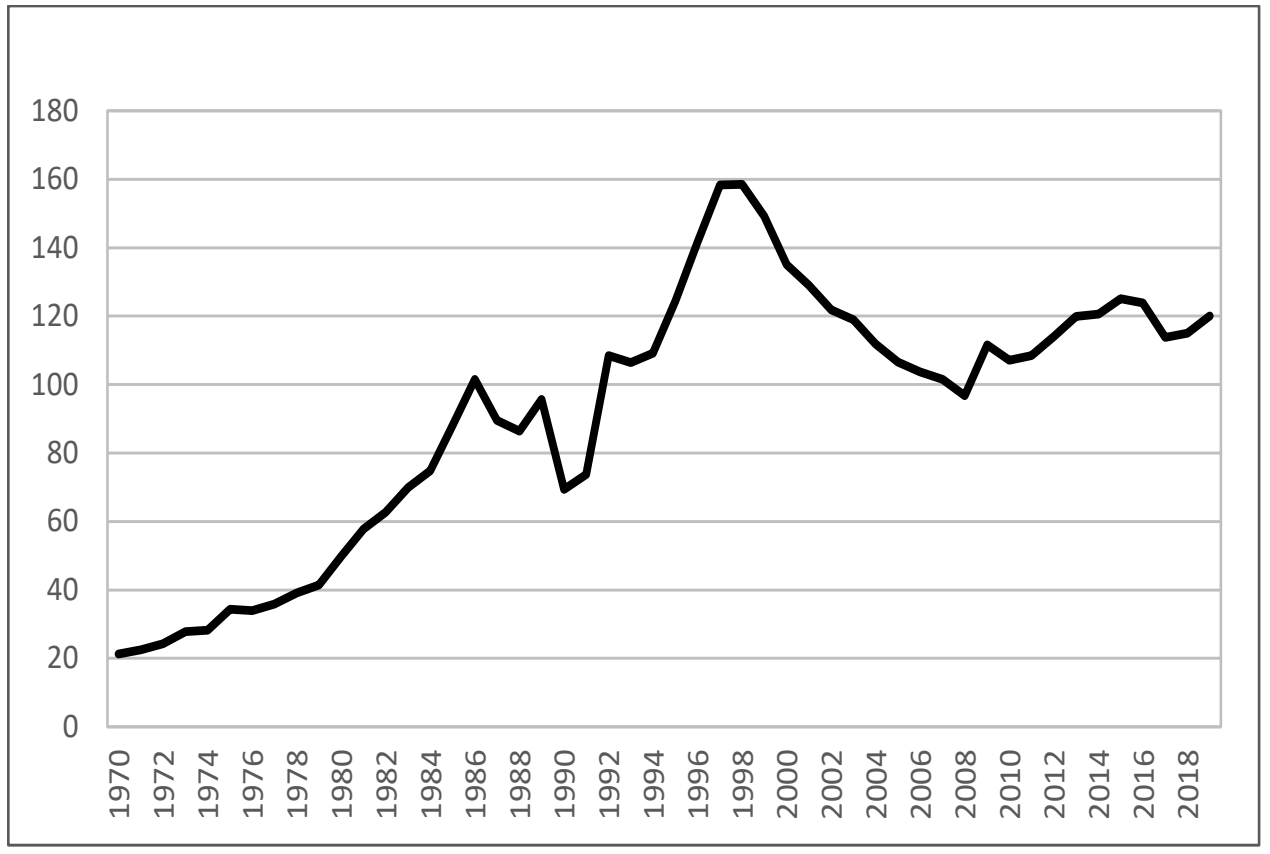

Figure 1. Malaysian domestic credit to private sector from 1970 to 2019 


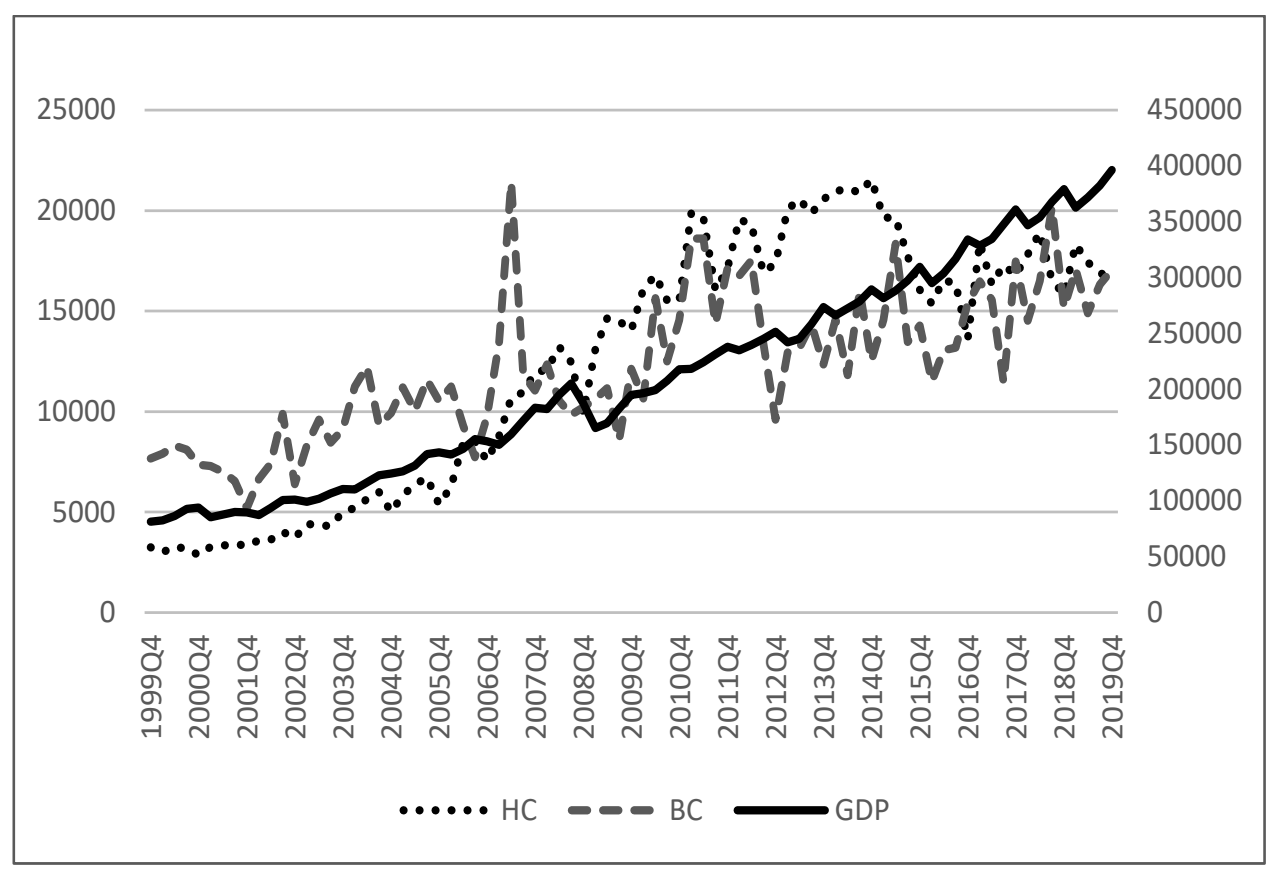

Figure 2. Gross domestic product (GDP), business credit and household credit of Malaysia from 1999: Q4 to 2019: Q4

by the financial sector tends to diminish and become negative in influencing economic growth. Since the Malaysian private sector credit ratio is greater than this threshold point from 1992 onwards (see Figure 1), except in 2008, it is crucial to examine whether more credit harms economic performance. Furthermore, the composition of credit in Malaysia has changed with an increasing share of household credit recently (see Figure 2), thus, it is vital to disentangle credit into business credit and household credit to assess the impacts of both on economic performance. As depicted in Figure 2, the household credit to GDP ratio has been higher than the business credit to GDP ratio since 2007: Q4. In fact, the increasing share of household credit has given it a dominant role in the balance sheets of the financial system. Motivated by recent literature that found business credit positively affects economic growth but household credit has a negative influence on economic growth, as well as more overall credit harming economic growth, this study adds to the existing finance-economic growth literature by analysing the hypothesis whether higher levels of credit are harmful or beneficial to economic performance in an economy with high ease of getting credit, specifically, Malaysia. To capture non-linearity of impacts, this study uses the quantile regression technique.

Specifically, this study examines the effects of bank lending to businesses (enterprises) and households on economic performance in Malaysia during the period 1999: Q4 to 2019: Q4, particularly whether increased credit advances or impedes economic 
performance for either category of recipients. If business credit outperforms household credit in promoting economic performance, then the credit policy should give priority to businesses rather than to households. This situation could arise because businesses tend to invest in productive activities and expand their business, which has a multiplier effect in the economy. On the other hand, household credit could be channelled into unproductive activities because it is used for paying personal loans and for consumption purposes, unless it is invested in human capital and/or micro enterprises (De Gregorio, 1996). Elekdag and Han (2015) demonstrated that internal factors are more influential than external factors in terms of driving fast credit growth in emerging Asia, where domestic monetary policy plays a vital role in managing fast credit growth in the region. Since the ratio of Malaysian domestic credit to private sector output was greater than 100\% from 1992 until 2019, Malaysia created an ideal laboratory to test whether more credit is good or harmful for economic performance. Quantile regression analysis examines this question by estimating the coefficient of credit at different points of the distribution. The method uses the conditional quantile functions for the dependent variables, and minimizes the weighted sum of absolute values of the residuals (Koenker \& Bassett, 1978; Koenker \& Hallock, 2001). Quantile regressions are also more robust with respect to the existence of outliers and non-normality (Buchinsky, 1995; Koenker \& Hallock, 2001).

A second question that is explored is whether good institutions play a role in moderating the effect of credit on economic performance in Malaysia. Without well-defined and effective institutions, such as low corruption, efficient bureaucratic performance, government stability, high transparency, rule of law and regulation, credit may be allocated to non-productive activities or sectors. With this possibility in mind, the interaction between institutional quality and credit is introduced in the model specification to assess whether the variables are substitutes or complements in influencing economic performance.

This study contributes to the literature in four aspects. First, we use a quantile regression to account for the possible non-linear relation between credit and economic performance. Second, this study focuses on Malaysia, an emerging market that has ranked number one among developing countries in terms of ease of getting credit, and so provides a good laboratory country with which to assess the role of credit in influencing economic performance. Third, this study incorporates the institutions variable as an interactive term to explain its influence on the credit - economic performance nexus. This study evaluates the interaction of credit and institutional quality in estimating the marginal effect of credit on economic performance. Fourth, this study employs the Balli and Sorensen (2013) demeaning method to generate the interaction between two variables, where each variable is converted to a demeaned variable first, then interacted with the other demeaned variable. This step tends to reduce any collinearity problem that might arise if both variables are interacted directly.

This paper is organised as follows: Section 2 reviews the literature; Section 3 presents the empirical model, econometric methodology, and the data; Section 4 discusses the empirical results; Section 5 offers a summary and final remarks. 


\section{Literature Review}

Beck et al. (2005), Hassan et al. (2011), Kar et al. (2011), Levine et al. (2000) and Rahaman (2011) have stated that credit provided by the banking sector to the private sector is an essential variable that impacts economic growth. In Mexico, however, Barrail (2020) discovered that increased household credit market participation leads to higher overall consumption volatility. Bahadir and Valev (2017) examined the convergence of household and business credit levels in 30 European economies for the period 1995 to 2013 . Their findings revealed that the process is most durable in transition nations with low starting levels of private sector lending that are catching up to Western Europe. Nevertheless, the convergence is often associated with household credit, which includes mortgages and consumer credit, which may restrict its economic growth effects.

Using the vector autoregressive (VAR) model, Sim and Lee (2020) found that the pro-cyclical behaviour of household credit outweighs the pro-cyclical behaviour of business credit not only in South Korea but also in 19 emerging nations. Their findings demonstrated that in the case of South Korea, pro-cyclical household credit complemented by collateral assets and worked by external debt generates countercyclical behaviour in interest rates. This intensifies credit market variation and stifles the growth of small and medium-sized businesses. In short, households with collateral assets play an active role as investors and consumers in emerging countries, signalling that large collateral loans to households in emerging economies' credit markets may amplify business cycle variation and stifle productive company growth. According to Laeven (2002), who also analysed the case of South Korea, the government's shift toward small and medium-sized enterprises (SMEs) has been beneficial because it has reduced financing constraints for many types of businesses and encouraged their growth in South Korea. According to Ma et al. (2019), the small and medium companies (SMEs) in China have limited access to loans from financial institutions. They found that credit restraints significantly reduce the opportunity of households to becoming entrepreneurs. They highlighted that institutions insufficiency play a vital role in influencing the pattern of financing problems in China.

The balance between mortgage and business credit growth, according to Bezemer and Zhang (2019), is a significant aspect in post-crisis macroeconomic susceptibility. The sample-average increase in credit structure (the percentage of residential mortgage credit in total credit) in 51 economies prior to the global financial crisis of 2007 is associated with a $2.1 \%$ average growth loss in the five years after the crisis. In terms of credit and current account components, Ekinci and Omay (2020) discovered that an increase in home credit generates a considerable reduction in the current account balance, whereas an increase in business loans has no effect. They came to the conclusion that household credit is to blame for the significant negative impact of credit expansion on the current account balance. They also showed that at lower levels of financial development, total and household loan growth rates have a bigger negative impact on the current account balance.

Based on credit and economic growth studies, finance promotes economic growth, but the appropriate size of finance is more important in fostering growth (Law \& 
Singh, 2014). Cecchetti and Kharroubi (2012) discovered that the ideal level for private sector credit granted by banks was close to $90 \%$ of GDP. They discovered that when the financial sector develops, the economy as a whole slows down. They claimed that this happens because the financial sector competes for limited resources with the rest of the economy. Arcand et al. (2012) also observed that when private sector credit approaches $100 \%$ of GDP, more finance begins to have a negative effect. They demonstrated that their findings are in line with the decreasing impact of financial development on economic growth.

Another strand of the empirical findings revealed that the relationship between finance and economic growth is non-linear, or more particularly, an inverted U-shaped relationship, with a turning point in the effect of private sector credit on economic growth. The comparative size of sorts of loans offered by financial markets is one of the possible explanations put out in the literature for such a relationship. Investment loans (business credit) facilitate financial development, according to Hung (2009), and these loans tend to stimulate economic growth, whereas non-productive consumption loans (household credit) tend to stifle economic progress. Beck et al. (2012) also claimed that company and household credits shape the link between finance and economic growth. They discovered that commercial credit, rather than household credit, had a greater growth influence on financial development. In addition, Sassi and Gasmi (2014) discovered that business credit had a beneficial impact on economic growth while household credit had a negative impact in 27 European Union countries. Another area of research is the role of institutions in the relationship between financial development and economic growth. Demetraides and Law (2006), Law and Azman-Saaini (2012), and Law et al. (2013) demonstrated that "quality finance, more growth" is a more proper proposition compared to "quantity finance, more growth" as documented in the literature.

\section{Empirical Model, Econometric Method and the Data}

\subsection{Empirical Model}

The following model specification is used to evaluate the effects of business credit and household credit on real gross domestic product (GDP). The empirical model is adopted from Sassi and Gasmi (2014) to examine the relative importance of business and household credit in promoting economic performance using the following linear equation:

$$
R G D P_{t}=\alpha+\beta_{1} T C_{\mathrm{t}}+\beta_{\mathrm{i}} X_{\mathrm{t}}+\varepsilon_{\mathrm{t}}
$$

where $R G D P$ is real GDP per capita, $T C$ is total credit, $X$ is a vector of controls (namely physical capital, labour growth, human capital, government expenditure, trade openness, FDI, inflation, institutions, where these variables are important determinants of economic performance), and $\varepsilon$ is an error term. Besides the physical capital stock, labour growth and human capital that appear in Equation (1), we also controlled for institutional quality because it has been found to enhance economic performance, for example, by Ahmed et al. (2021), Boateng et al. (2021), Corradini (2020), Knack 
and Keefer (1995), and Rodrik et al. (2004). Trade openness is included in the model because it has been established to promote economic performance (Montalbano, 2011; Musila \& Yiheyis, 2015). However, inflation has a negative effect on economic performance (Eggoh \& Khan, 2014; Vinayagathasan, 2013). In addition, government expenditure is included as another control variable because government expenditure has been found to stimulate economic performance, as shown by Hajamini and Falahi (2018) and Wu et al. (2010). Foreign direct investment (FDI) is also included because it has been found to spur economic performance as indicated by Baharumshah and Almasaied (2009), Goh et al. (2017) and Pegkas (2015). Since the main objective of the study is to examine the roles of business credit and household credit, Equation (2) splits credit into two components as follows:

$$
R G D P C_{t}=\alpha+\beta_{1} B C_{t}+\beta_{2} H C_{t}+\beta_{i} X_{t}+\varepsilon_{t}
$$

where $B C$ is business credit and $H C$ is household credit.

According to Demetriades and Law (2006), financial development tends to have greater effect on economic performance when the financial system is situated within a good institutional structure. Law and Azman-Saini (2012) highlighted that better institutions are important in explaining financial development. Law et al. (2013) also suggested that the financial depth-economic growth relationship is affected by institutional quality, thus backing up the idea that well-developed finance promotes economic performance. Therefore, this study also analyses the interaction between credit and institutions (INS) in influencing economic performance as follows:

$$
\begin{aligned}
& R G D P_{t}=\alpha+\beta_{1} B C_{\mathrm{t}}+\beta_{2} H C_{\mathrm{t}}+\beta_{3} I N S_{\mathrm{t}}+\beta_{4}[B C \times I N S]_{\mathrm{t}}+\beta_{\mathrm{i}} X_{\mathrm{t}}+\varepsilon_{\mathrm{t}} \\
& R G D P_{t}=\alpha+\beta_{1} B C_{\mathrm{t}}+\beta_{2} H C_{\mathrm{t}}+\beta_{3} I N S_{\mathrm{t}}+\beta_{4}[H C \times I N S]_{\mathrm{t}}+\beta_{\mathrm{i}} X_{\mathrm{t}}+\varepsilon_{\mathrm{t}}
\end{aligned}
$$

In this study, the Balli and Sorensen (2013) interaction term method is employed for Equations ( 3 ) and (4) namely the demeaning method. Each observation of business credit, household credit and institutions are deducted the mean value over the sample period. The demeaning method tends to reduce the collinearity problem of the independent variables as follows:

$$
\begin{aligned}
& R G D P_{t}=\alpha+\beta_{1} B C_{\mathrm{t}}+\beta_{2} H C_{\mathrm{t}}+\beta_{3} I N S_{\mathrm{t}}+\beta_{4}[(B C-\overline{B C}) \times(I N S-\overline{I N S})]_{\mathrm{t}}+\beta_{\mathrm{i}} X_{\mathrm{t}}+\varepsilon_{\mathrm{t}} \\
& R G D P_{t}=\alpha+\beta_{1} B C_{\mathrm{t}}+\beta_{2} H C_{\mathrm{t}}+\beta_{3} I N S_{\mathrm{t}}+\beta_{4}[(H C-\overline{H C}) \times(I N S-\overline{I N S})]_{\mathrm{t}}+\beta_{\mathrm{i}} x_{\mathrm{t}}+\varepsilon_{\mathrm{t}}
\end{aligned}
$$

The demeaning method is only applied for the interaction term and not the other regressors. If applied to all variables, then the two interaction variables will be the same with the original series datasets used in the estimation. Both business credit and household credit plus institutional variables are interacted in the same regression to assess the relative importance of institutions in influencing both credit variables. The equation based on the demeaning method is as follows:

$$
\begin{aligned}
R G D P_{t}= & \alpha+\beta_{1} B C_{\mathrm{t}}+\beta_{2} H C_{\mathrm{t}}+\beta_{3} I N S_{\mathrm{t}}+\beta_{4}[(B C-\overline{B C}) \times(I N S-\overline{I N S})]_{\mathrm{t}}+ \\
& \beta_{5}[(H C-\overline{H C}) \times(I N S-\overline{I N S})]_{\mathrm{t}}+\beta_{\mathrm{i}} \mathrm{x}_{\mathrm{t}}+\varepsilon_{\mathrm{t}}
\end{aligned}
$$




\subsection{Econometric Methodology: Quantile Regression}

To evaluate whether credit and economic performance have a non-linear relationship, this study uses a quantile regression to account for the impacts under different credit conditions (Koenker \& Hallock, 2001). The motivation for choosing this non-linear methodology can be described by the fact that distribution of credit allowances is best captured by using several quantiles. A quantile regression can reveal information on the asymmetric and non-linear effects of conditional variables on the dependent variable. It can capture the effect of abrupt changes in credit on the sign and intensity of economic performance across different quantiles. ${ }^{1}$ The standard linear regression technique estimates the average relationship between a set of regressors $(x)$ and the outcome variable $(y)$ based on the conditional mean function $E(y \mid x)$, which provides only a partial view of the relationship. As this study analyses the relationship at different points in the conditional distribution of real GDP per capita, the quantile regression offers such capability in examining the relationship between credit and economic performance.

The linear quantile regression (QR) model can be expressed as follows:

$$
\mathrm{q}_{\tau}\left(\operatorname{RGDPC}_{\mathrm{t}} \mid \mathrm{I}_{\mathrm{t}}\right)=\alpha_{\tau}+\beta_{\tau} C_{\mathrm{t}}+\varepsilon_{\mathrm{t}}
$$

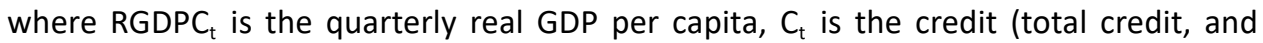
two sub-components, business credit and household credit) and $I_{t}$ is the vector of control variables. $\beta_{\tau}$ is the slope coefficient quantifying the effect of credit on economic performance at quantile $\tau$ and $\varepsilon_{\mathrm{t}}$ is the error term.

The estimates of $\alpha_{\tau}$ and $\beta_{\tau}$ in Equation (9) are defined as the keys to:

$$
\min _{\alpha \tau, \beta \tau} \sum_{t=1}^{T} \rho_{\tau}\left(R G D P C_{t}-\alpha_{\tau}-\beta_{\tau} C_{t}\right)
$$

where $\rho_{\tau}(z)$ is the check function given by $\rho_{\tau}(z)=z\left(\tau-1_{|z \leq 0|}\right)$, where $1_{\lfloor z \leq 0\rfloor}$ is the indicator function. As clarified in Koenker and Hallock (2001), the function $\rho_{\tau}(z)$ enforces dissimilar weights on positive and negative residuals contingent on the value of $\tau$; when $\tau=0.5$, this is the median estimator.

\subsection{The Data}

This study utilises quarterly time series datasets covering the period from 1999: Q4 to 2019: Q4 with 81 observations. ${ }^{2}$ The sources of the data are from the Monthly Statistical Bulletin, published by Bank Negara Malaysia (BNM) or the Central Bank of Malaysia and Department of Statistics, Malaysia. The real gross domestic product (GDP) per capita is obtained from the Monthly Statistical Bulletin, published by BNM. Business credit $(\mathrm{BC})$ consists of loans approved in agriculture, manufacturing and services, while

1 Sukmana and Ibrahim (2018) used the quantile regression approach to examine the relationship between financial access and inequality.

2 Since real GDP per capita, business credit, household credit, government expenditure, trade openness and inflation datasets are available on a quarterly basis, this study uses the quarterly data instead of yearly data because there are more observations and variations at the quarterly interval. In addition, the main aim is to analyse the effects of business credit and household credit on economic performance. The data commenced from 1999 to avoid the 1997-1998 East Asian financial crisis period which may distort the estimations. 
household credit $(\mathrm{HC})$ consists of loans approved by the financial system to households. Both datasets are naturally expressed in real terms (i.e. both series have been deflated by the consumer price index and transformed into logarithmic terms). The source of both credit datasets is from the Monthly Statistical Bulletin, BNM.

The capital stock is obtained from the gross investment figures following the perpetual inventory method. Initial capital stocks are computed using the conjecture that over long periods of time, output and capital grow at the same rate. A depreciation rate of $6 \%$ and the average economic growth rate of the initial 5 years are used to create the initial level of capital stock (see Hall \& Jones, 1999). Total population is used to measure the labour growth rate and human capital as proxied by life expectancy (World Bank). Physical capital, population growth and human capital datasets have an annual frequency, together with other control variables such as FDI and institutional quality. All these variables are interpolated into a quarterly frequency. ${ }^{3}$ Government expenditure, trade openness and inflation variables are in quarterly basis. All these datasets are obtained from BNM except for FDI and institutional quality, which are obtained from the United Nations Conference on Trade and Development (UNCTAD) and the International Country Risk Guide (ICRG), respectively.

Table 1 reports the descriptive statistics of all variables in their original unit of measurement. As shown in Table 1, the mean, standard deviation, minimum and maximum values of household credit are higher than the business credit. This indicates that household credit is more dominant and with respect to the overall average from 1999: Q4 to 2019: Q4, about 62\% of Malaysia's credit is allocated to household. The mean value of institutions variable is 31 out of 50 , and the standard deviation is 2.86 . The population growth variable demonstrates the smallest standard deviation among

Table 1. Descriptive statistics

\begin{tabular}{llrrrr}
\hline Variable & $\begin{array}{l}\text { Unit of } \\
\text { measurement }\end{array}$ & Mean & $\begin{array}{l}\text { Standard } \\
\text { deviation }\end{array}$ & Minimum & Maximum \\
\hline Real GDP per capita & Ringgit (million, & 24782.70 & 8159.26 & 13275.17 & 37682.43 \\
& 2010 constant prices) & & & & \\
Business credit & Ringgit (million) & 12245.95 & 3608.17 & 3567.53 & 16336.46 \\
Household credit & Ringgit (million) & 12376.78 & 6293.47 & 2858.84 & 21552.52 \\
Total credit & Ringgit (million) & 24622.73 & 9314.86 & 8533.22 & 38493.31 \\
Population growth & Percent & 1.79 & 0.24 & 1.51 & 2.46 \\
Physical capital & Ringgit (million) & 39334.10 & 17211.85 & 16371.00 & 75880.00 \\
Human capital & Number of year & 73.77 & 0.58 & 72.74 & 74.71 \\
Trade openness & Percent of GDP & 179.27 & 23.73 & 151.43 & 245.62 \\
Government expenditure & Percent of GDP & 12.15 & 2.76 & 7.77 & 18.77 \\
FDI & Percent of GDP & 44.84 & 8.36 & 31.64 & 66.30 \\
Inflation & Percent & 2.24 & 1.56 & -1.99 & 8.21 \\
Institutions & Scale 1 - 50 & 30.96 & 2.86 & 28.45 & 37.60 \\
\hline
\end{tabular}

3 The Eviews software is used to convert the annual data to quarterly data. 
the variables used in the analysis. The earlier Figure 2 depicts the level of both the business credit and household credit as well as real GDP in Malaysia from 1999: Q4 to 2019: Q4. Credit environments in Malaysia have been encouraging to the financing needs of the economy, and they reveal greater financial development in Malaysia. Since 2007, household credit has become greater than business credit in Malaysia. The period of strong credit growth in Malaysia corresponds with a period of wide-ranging restructurings undertaken to build up the banking sector after the 1997-1998 Asian financial crisis. The enlargement of credit to businesses and households contributes to financial markets development and speed up economic growth, enhancing investment and consumption activities. However, as shown in Figure 2, excessive household credit that outperforms business credit can pose destabilising risks to the economy and to the financial system. According to Hung (2009), financial development facilitates investment loans that promote economic growth, whereas consumption loans that are nonproductive have a tendency to hamper economic growth. He repeated the non-linear relationships between finance and economic growth by incorporating consumption loans with investment loans in a standard model of asymmetric information.

\section{Empirical Results}

Table 2 reports the quantile regression by estimating Equations (8) and (9) at five quantiles, namely the 10th, 25th, 50th, 75th and 90th quantiles, using the total credit and explanatory variables. The interpretation of the basic proposition that quantiles matter in the relation between credit and real GDP per capita due to the non-linear effect of credit and economic performance is demonstrated in recent literature. The quantile regression can detect the non-linear effect through the coefficients of the

Table 2. Result of quantile regression (credit = total credit)

\begin{tabular}{lccccc}
\hline Variables & $(1)$ & $(2)$ & $(3)$ & $(4)$ & $(5)$ \\
Physical capital & $\mathrm{q} 10$ & $\mathrm{q} 25$ & $\mathrm{q} 50$ & $\mathrm{q} 75$ & $\mathrm{q} 90$ \\
& $0.345^{* *}$ & 0.225 & 0.153 & 0.175 & $0.366^{* *}$ \\
Human capital & $(0.148)$ & $(0.148)$ & $(0.148)$ & $(0.144)$ & $(0.177)$ \\
& 17.65 & 24.25 & 27.41 & 26.17 & 2.084 \\
Population growth & $(18.14)$ & $(17.32)$ & $(16.70)$ & $(15.71)$ & $(15.43)$ \\
& -0.525 & -0.139 & -0.0919 & -0.206 & -0.525 \\
Total credit & $(0.797)$ & $(0.739)$ & $(0.728)$ & $(0.588)$ & $(0.449)$ \\
& 0.113 & $0.215^{* * *}$ & $0.230^{* * *}$ & $0.180^{* * *}$ & $0.319^{* * *}$ \\
Constant & $(0.0747)$ & $(0.0643)$ & $(0.0484)$ & $(0.0565)$ & $(0.0936)$ \\
& -68.42 & -96.78 & -109.7 & -104.1 & -3.628 \\
Pseudo R & $(77.09)$ & $(73.40)$ & $(70.81)$ & $(66.27)$ & $(64.66)$ \\
Observations & 0.9024 & 0.9141 & 0.9126 & 0.9031 & 0.8811 \\
\hline
\end{tabular}

Note: The dependent variable for the quantile regression is real GDP per capita. Figures in parentheses are standard errors. $* * * * *$ and $*$ denote significance at $1 \%, 5 \%$ and $10 \%$ levels, respectively. 
credit variable. This study also includes other control variables that affect economic performance.

Starting from Table 2 and focusing on the total credit (business and household), the quantile regression shows that total credit is a significant positive determinant of economic performance throughout all quantiles, except for the 10th quantile. This finding demonstrates that credit plays a vital role in supporting economic performance in Malaysia. The total credit is insignificant at the 10th quantile because lower credit is insufficient to promote economic performance. At a lower credit level, it does not play a critical role in channelling funds from surplus units to deficit units and hence, stimulate economic performance. The other coefficient estimates are consistent with theory, where physical capital and human capital are positively associated with economic performance, whereas population growth is negative but insignificant determinant of economic performance.

Table 3 repeats the same estimation but using both business credit and household credit in the model specification. Business credit is a statistically significant determinant of economic performance at the $5 \%$ level except in the 10th quantile, but household credit is insignificant. This finding reveals that business credit has a greater role compared to household credit. Household credit has a weak positive significant impact on economic performance in the 90th quantile. Again, all three control variables are in line with theory where physical capital and human capital have a positive sign and population growth has a negative sign. These results reflect those of Beck et al. (2012) and Sassi and Gasmi (2014), who found that business credit plays a greater role than household credit in promoting economic performance.

Table 3. Result of quantile regression (business credit and household credit)

\begin{tabular}{lccccc}
\hline Variables & $(1)$ & $(2)$ & $(3)$ & $(4)$ & $(5)$ \\
\hline Physical capital & $\mathrm{q} 10$ & $\mathrm{q} 25$ & $\mathrm{q} 50$ & $\mathrm{q} 75$ & $\mathrm{q} 90$ \\
\hline Human capital & $0.414^{* * *}$ & $0.266^{*}$ & 0.179 & 0.198 & $0.366^{* *}$ \\
& $(0.146)$ & $(0.141)$ & $(0.137)$ & $(0.125)$ & $(0.161)$ \\
Population growth & 8.994 & 20.28 & $28.78^{*}$ & $28.02^{*}$ & 2.659 \\
& $(18.34)$ & $(17.10)$ & $(16.96)$ & $(15.07)$ & $(17.35)$ \\
Business credit & -1.107 & -0.428 & -0.0751 & -0.179 & -0.478 \\
& $(0.807)$ & $(0.781)$ & $(0.691)$ & $(0.501)$ & $(0.427)$ \\
Household credit & 0.067 & $0.108^{* *}$ & $0.117^{* *}$ & $0.087^{* *}$ & $0.121^{* *}$ \\
& $(0.053)$ & $(0.046)$ & $(0.046)$ & $(0.035)$ & $(0.058)$ \\
Constant & 0.0128 & 0.0811 & 0.0834 & 0.0608 & $0.198^{*}$ \\
& $(0.077)$ & $(0.087)$ & $(0.089)$ & $(0.081)$ & $(0.116)$ \\
Pseudo R & -31.19 & -79.56 & -115.5 & $-111.8 *$ & -5.925 \\
Observations & $(77.97)$ & $(72.63)$ & $(71.80)$ & $(63.55)$ & $(72.76)$ \\
\hline
\end{tabular}

Note: The dependent variable for the quantile regression is real GDP per capita. Figures in parentheses are standard errors. $* * *, * *$ and $*$ denote significance at $1 \%, 5 \%$ and $10 \%$ levels, respectively. 


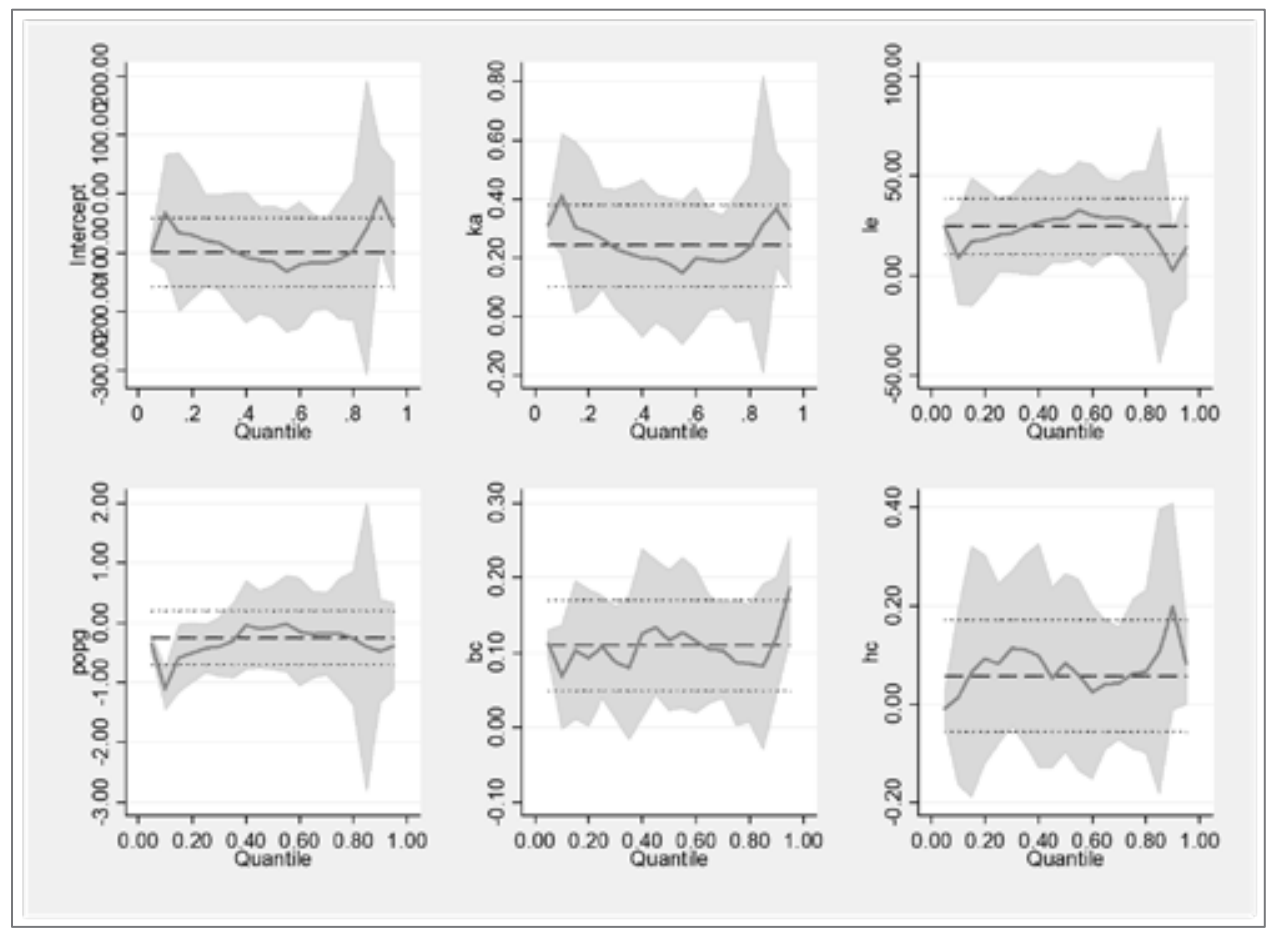

Figure 3. Quantile regressions diagram of basic model - business credit, household credit and economic performance

Note: The vertical axis is the estimated coefficient whereas the horizontal axis is the quantile distribution (in percent).

Figure 3 presents the estimated slope coefficients of economic performance with two different types of credit of Equation (2) and the control variables. The quantile regressions offer a rich explanation of the dynamics of the reaction of economic performance to business credit (bc) and household credit (hc). The dotted line displays the quantile regression estimates for the quantiles ranging from 0.10 to 0.90 . The straight solid line signifies the OLS coefficient. The two dashed lines represent the conventional 95\% confidence intervals for the OLS coefficient, and the shaded grey area plots a $95 \%$ pointwise confidence band for the quantile regression estimates. The business credit and household credit diagrams show linear coefficients and confirm no non-linear relationship between both credits and economic performance.

Table 4 reports the empirical results where all explanatory variables namely government expenditure, foreign direct investment (FDI), trade openness, inflation and institutions are counted in the model specification. Turning to the empirical results of business credit and household credit, business credit is a statistically significant determinant of economic performance in the 50th and 75th quantiles at the $5 \%$ level. Household credit, however, is insignificant throughout all the quantiles. Government expenditure is insignificant and has a negative sign in all quantiles. The foreign direct investment (FDI) is a significant determinant of economic performance in the 75th and 
Table 4. Result of expanded quantile regression (business credit and household credit)

\begin{tabular}{lccccc}
\hline \multirow{2}{*}{ Variables } & $(1)$ & $(2)$ & $(3)$ & $(4)$ & $(5)$ \\
\hline Physical capital & $\mathrm{q} 10$ & $\mathrm{q} 25$ & $\mathrm{q} 50$ & $\mathrm{q} 75$ & $\mathrm{q} 90$ \\
\hline Human capital & -0.029 & 0.096 & $0.128^{*}$ & $0.226^{* * *}$ & $0.189^{* * *}$ \\
& $(0.137)$ & $(0.092)$ & $(0.074)$ & $(0.068)$ & $(0.070)$ \\
Population growth & $48.16^{* *}$ & $26.15^{* *}$ & $22.01^{* *}$ & 9.073 & $17.28^{*}$ \\
& $(20.08)$ & $(12.86)$ & $(10.50)$ & $(10.57)$ & $(10.29)$ \\
Business credit & -0.417 & -0.011 & -0.151 & -0.670 & -0.681 \\
& $(0.835)$ & $(0.603)$ & $(0.438)$ & $(0.436)$ & $(0.415)$ \\
Household credit & 0.023 & 0.008 & $0.127^{* *}$ & $0.102^{* *}$ & 0.030 \\
& $(0.061)$ & $(0.039)$ & $(0.054)$ & $(0.048)$ & $(0.023)$ \\
Government expenditure & 0.046 & 0.130 & 0.091 & 0.003 & 0.046 \\
& $(0.116)$ & $(0.092)$ & $(0.059)$ & $(0.031)$ & $(0.057)$ \\
FDI & -0.082 & -0.037 & -0.029 & -0.013 & -0.057 \\
& $(0.051)$ & $(0.035)$ & $(0.026)$ & $(0.025)$ & $(0.034)$ \\
Trade openness & 0.046 & 0.065 & 0.073 & $0.130^{* *}$ & $0.121^{* *}$ \\
& $(0.123)$ & $(0.093)$ & $(0.061)$ & $(0.059)$ & $(0.054)$ \\
Inflation & $0.303^{*}$ & $0.2638^{* *}$ & $0.283^{* * *}$ & $0.161^{* *}$ & 0.136 \\
& $(0.165)$ & $(0.123)$ & $(0.079)$ & $(0.078)$ & $(0.088)$ \\
Institutions & 0.816 & 0.644 & 0.710 & $1.119^{* *}$ & $1.110^{* * *}$ \\
& $(0.915)$ & $(0.676)$ & $(0.481)$ & $(0.433)$ & $(0.359)$ \\
Constant & 0.085 & 0.119 & $0.139 * *$ & $0.195^{* *}$ & $0.238^{* *}$ \\
& $(0.222)$ & $(0.164)$ & $(0.065)$ & $(0.087)$ & $(0.116)$ \\
Pseudo R ${ }^{2}$ & $-199.2^{* *}$ & $-106.9 *$ & $-89.52^{* *}$ & -33.99 & -67.94 \\
Observations & $(85.27)$ & $(54.55)$ & $(44.57)$ & $(44.85)$ & $(43.64)$ \\
\hline & 0.9343 & 0.9522 & 0.9559 & 0.9558 & 0.9542 \\
& 81 & 81 & 81 & 81 & 81 \\
\hline
\end{tabular}

Note: The dependent variable for the quantile regression is real GDP per capita and include all control variables. Figures in parentheses are standard errors. $* * *, * *$ and $*$ denote significance at $1 \%, 5 \%$ and $10 \%$ levels, respectively.

90th quantiles, where the quantiles are high. This finding is consistent with Alfaro et al. (2004) who found that FDI alone plays a vague role in contributing to economic growth. Nevertheless, countries with well-developed financial systems gain significantly from FDI (Azman-Saini et al., 2010).

Trade openness as a control variable in Table 4 also shows a significant result throughout all quantiles. This finding is in line with Musila and Yiheyis (2015), who showed that trade openness is found to have positively affected economic performance. Mustafa et al. (2017) also demonstrated that economic performance is sustainable only when accompanied by trade openness policies in attaining higher growth and human development. With respect to the inflation variable, it has a positive effect on economic performance. Vinayagathasan (2013) suggested that inflation hurts growth when it exceeds a $5.43 \%$ threshold level but has no effect below this level. Baharumshah et al. (2016) confirmed the negative growth effects in high inflation rate 
countries, and the growth enhancing effects in low inflation countries. Since Malaysia's inflation rate has been below $5 \%$ since 2000 , it has had a positive effect on economic performance and has yet to rise above the stated threshold level. The institutions variable is a significant determinant of economic performance in the 50th, 75th and 90th quantiles. The effects of institutions in promoting economic performance are in line with Ahmed et al. (2021), Boateng et al. (2021), Corradini (2020) and Knack and Keefer (1995), who find better institutions can have a large effect on output. ${ }^{4}$

\section{1 Interaction between Institutions and Credit}

Equations (3) and (4) include estimations of the interaction between institutions and business credit, and the interaction between institutions and household credit, respectively. The empirical results are presented in Tables 5 and 6. As shown in Table 5, the

Table 5. Result of quantile regression (interaction between business credit and institutions)

\begin{tabular}{|c|c|c|c|c|c|}
\hline Variables & (1) & (2) & (3) & (4) & $\begin{array}{l}\text { (5) } \\
\text { q90 }\end{array}$ \\
\hline Physical capital & $\begin{array}{c}0.453^{* * *} \\
(0.124)\end{array}$ & $\begin{array}{c}0.331 * * * \\
(0.088)\end{array}$ & $\begin{array}{c}0.431^{* * *} \\
(0.075)\end{array}$ & $\begin{array}{c}0.351^{* * *} \\
(0.083)\end{array}$ & $\begin{array}{c}0.358^{* * *} \\
(0.103)\end{array}$ \\
\hline Human capital & $\begin{array}{c}3.213 \\
(15.18)\end{array}$ & $\begin{array}{c}14.86 \\
(10.21)\end{array}$ & $\begin{array}{c}2.335 \\
(9.642)\end{array}$ & $\begin{array}{c}15.80 \\
(11.09)\end{array}$ & $\begin{array}{c}11.58 \\
(12.82)\end{array}$ \\
\hline Population growth & $\begin{array}{l}-0.774 \\
(0.463)\end{array}$ & $\begin{array}{l}-0.561^{*} \\
(0.293)\end{array}$ & $\begin{array}{c}-0.777 * * * \\
(0.270)\end{array}$ & $\begin{array}{l}-0.287 \\
(0.289)\end{array}$ & $\begin{array}{l}-0.275 \\
(0.392)\end{array}$ \\
\hline Business credit (BC) & $\begin{array}{c}-2.501^{* *} \\
(1.207)\end{array}$ & $\begin{array}{c}-2.126 * * \\
(1.003)\end{array}$ & $\begin{array}{c}-1.850 * * \\
(0.900)\end{array}$ & $\begin{array}{c}-1.961^{* *} \\
(0.865)\end{array}$ & $\begin{array}{l}-1.325 \\
(1.229)\end{array}$ \\
\hline Household credit & $\begin{array}{c}0.133 \\
(0.098)\end{array}$ & $\begin{array}{c}0.091 \\
(0.082)\end{array}$ & $\begin{array}{c}0.134 \\
(0.081)\end{array}$ & $\begin{array}{c}0.115 \\
(0.083)\end{array}$ & $\begin{array}{c}0.189 * * \\
(0.088)\end{array}$ \\
\hline Institutions (INS) & $\begin{array}{c}6.869 * * \\
(3.119)\end{array}$ & $\begin{array}{c}5.682^{* *} \\
(2.554)\end{array}$ & $\begin{array}{c}4.953^{* *} \\
(2.280)\end{array}$ & $\begin{array}{c}5.322^{* *} \\
(2.226)\end{array}$ & $\begin{array}{c}3.804 \\
(3.180)\end{array}$ \\
\hline$B C \times I N S$ & $\begin{array}{c}0.729 * * \\
(0.350)\end{array}$ & $\begin{array}{c}0.603^{* *} \\
(0.289)\end{array}$ & $\begin{array}{l}0.517^{*} \\
(0.261)\end{array}$ & $\begin{array}{c}0.549 * * \\
(0.254)\end{array}$ & $\begin{array}{c}0.365 \\
(0.362)\end{array}$ \\
\hline Constant & $\begin{array}{l}-31.02 \\
(62.27)\end{array}$ & $\begin{array}{l}-75.98 \\
(45.70)\end{array}$ & $\begin{array}{l}-21.09 \\
(42.59)\end{array}$ & $\begin{array}{l}-79.53^{*} \\
(46.74)\end{array}$ & $\begin{array}{c}-56.88 \\
(50.74)\end{array}$ \\
\hline Pseudo $\mathrm{R}^{2}$ & 0.9223 & 0.9343 & 0.9374 & 0.9343 & 0.9234 \\
\hline Observations & 81 & 81 & 81 & 81 & 81 \\
\hline \multicolumn{6}{|l|}{ Marginal effect } \\
\hline Mean & $-0.0014 * *$ & $0.3994^{* *}$ & $0.0753 * * *$ & $0.0765^{* *}$ & 0.0721 \\
\hline Minimum & 0.0602 & 0.4419 & 0.1190 & 0.1229 & 0.1029 \\
\hline Maximum & -0.1431 & $0.3016 * *$ & $-0.0252 * *$ & $-0.0302 * *$ & 0.0011 \\
\hline
\end{tabular}

Note: The dependent variable for the quantile regression is real GDP per capita. Figures in parentheses are standard errors. $* * *, * *$ and $*$ denote significance at $1 \%, 5 \%$ and $10 \%$ levels, respectively.

4 Differences in institutions refer to different institutional quality whether it is weak or strong. If a country has strong institutions, then it will promote economic performance. 
Table 6. Result of quantile regression (interaction between household credit and institutions)

\begin{tabular}{lccccc}
\hline & $(1)$ & $(2)$ & $(3)$ & $(4)$ & $(5)$ \\
Variables & $\mathrm{q} 10$ & $\mathrm{q} 25$ & $\mathrm{q} 50$ & $\mathrm{q} 75$ & $\mathrm{q} 90$ \\
\hline Physical capital & $0.405^{* * *}$ & $0.347^{* * *}$ & $0.400^{* * *}$ & $0.334^{* * *}$ & $0.377^{* * *}$ \\
& $(0.131)$ & $(0.107)$ & $(0.079)$ & $(0.082)$ & $(0.116)$ \\
Human capital & 14.73 & 11.43 & 7.893 & 15.87 & 6.173 \\
& $(15.15)$ & $(11.23)$ & $(9.023)$ & $(10.79)$ & $(16.44)$ \\
Population growth & -0.398 & $-0.654^{*}$ & $-0.564^{*}$ & -0.378 & -0.500 \\
& $(0.557)$ & $(0.370)$ & $(0.301)$ & $(0.303)$ & $(0.502)$ \\
Business credit & 1.225 & $1.307^{*}$ & $1.851^{* *}$ & $1.747^{* *}$ & 1.658 \\
& $(0.923)$ & $(0.758)$ & $(0.723)$ & $(0.823)$ & $(1.188)$ \\
Household credit (HC) & 0.008 & 0.057 & 0.055 & 0.091 & 0.094 \\
& $(0.068)$ & $(0.047)$ & $(0.039)$ & $(0.080)$ & $(0.082)$ \\
Institutions (INS) & 3.416 & $3.600^{*}$ & $5.045^{* *}$ & $4.883^{* *}$ & 4.558 \\
& $(2.522)$ & $(2.122)$ & $(1.960)$ & $(2.174)$ & $(3.138)$ \\
HC x INS & -0.330 & -0.351 & $-0.501^{* *}$ & $-0.481^{* *}$ & -0.432 \\
& $(0.269)$ & $(0.226)$ & $(0.213)$ & $(0.238)$ & $(0.342)$ \\
Constant & -68.09 & -54.29 & -44.90 & $-78.03^{*}$ & -36.36 \\
& $(64.50)$ & $(48.34)$ & $(38.73)$ & $(44.64)$ & $(64.90)$ \\
Pseudo R ${ }^{2}$ & 0.9171 & 0.9306 & 0.9352 & 0.9315 & 0.9233 \\
Observations & 81 & 81 & 81 & 81 & 81 \\
\hline Marginal Effect & & & & & \\
Mean & 0.0922 & 0.1022 & 0.1313 & 0.7824 & 0.1751 \\
Minimum & 0.1201 & 0.1318 & 0.1736 & 0.8061 & 0.2116 \\
Maximum & 0.0281 & 0.0339 & 0.0339 & 0.7278 & 0.0911 \\
\hline
\end{tabular}

Note: The dependent variable for the quantile regression is real GDP per capita. Figures in parentheses are standard errors. $* * *, * *$ and $*$ denote significance at $1 \%, 5 \%$ and $10 \%$ levels, respectively.

estimated coefficients on the interaction between the institutions variable and business credit are positive in the 10th until 75th quantiles. The opposite coefficient results are observed in Table 6 where the interaction between institutions and household credit is negative. Brambor et al. (2006) pointed out that the coefficient $\beta_{1}$ on business credit only captures the effect of business credit on economic performance when the institutions variable is zero. Similarly, $\beta_{3}$ only captures the effect of institutions on economic performance when business credit does not exist. Therefore, a positive/ negative sign obtained for the coefficient of $\beta_{1}$ and $\beta_{3}$ does not explain the direct correlation between business credit and institutions with economic performance. In contrast, institutions variable as the moderator is supposed to shield the influence of improved business credit on economic performance, therefore $\beta_{4}$, is supposed to be marginally positive or negative contingent on the effect of institutions on business credit.

As reported in Tables 5 and 6, the institutional individual effects have the most impact on economic performance compared to other control variables. An improvement in institutions measure tends to promote a substantial improvement in economic 
performance at all quantiles. The interaction term coefficients between institutions and both types of credit are positive. For business credit presented in Table 5, the interaction terms are significant at the conventional level in the 10th, 25th, 50th and 75th quantiles, which indicates that the marginal effect of these quantiles are significant. Thus, when there are both good institutions and bank credit then economic performance will increase, although this effect is smaller. For example, in quantile 50th, if economic performance is up to $50 \%$, then business credit will contribute about $0.0753 \%$ to economic performance. Nevertheless, in the 10th quantile, the value is negative which implies insufficient business credit is available to promote economic performance.

Table 5 shows that the coefficient on business credit is negative, so increased business credit leads to a fall in economic performance. However, empirical findings imply that increased business credit without good institutions is not good for economic performance. The results demonstrate that if compared with Table 4 without the interaction term, business credit is positive and a statistically significant determinant of economic performance. If an economy has rapid credit expansion but poor bankruptcy and legal structures, then it might end up with some of the problems in the lead-up to the 1997-1998 East Asian financial crisis. This effect is more pronounced in the lower quantiles.

The marginal effect where institutions are evaluated at the minimum level shows an insignificant result throughout all quantiles. However, at the mean level in the 50th and 75th quantiles, it demonstrates a positive effect. This finding reveals that if the economic growth is greater than $50 \%$ and up until the $75 \%$ level, a change of $1 \%$ in business credit is associated with an increase of $0.08 \%$ in GDP growth. At the maximum level in the 50th and 75th quantiles, it demonstrates a negative effect. This finding reveals that if the economic growth is greater than $50 \%$ and up until the $75 \%$ level, a change of $1 \%$ in business credit is associated with a decrease of $0.03 \%$ in GDP performance. This result corroborates the finding of the diminishing effect of finance on economic growth in recent literature.

With respect to household credit as presented in Table 6, it is clear that a majority of the effect is again through institutions. In this case where the household credit without institutions is positive but insignificant, it indicates an economy still get some benefits. Nevertheless, the results reveal that in fact the interaction of institutions with household credit is a dampening effect on economic performance. This might be due to it restraining the use of household credit for speculative purpose and consumption. The empirical results of the interaction terms between household credit and institutions are negative and significant in the 50th and 75th quantiles. Nevertheless, when we evaluate the marginal effect, all household credit are insignificant determinants of economic growth.

Table 7 presents the results when both credit variables are interacted with institutions at different quantiles. Our main focus will be the interaction term between both credit variables with institutions. The interaction terms between business credit and institutions are positive and statistically significant determinant of economic performance at the 50th and 75th quantiles. The finding suggests that business credit tends to enhance economic performance if Malaysia has good institutions, which is in line with Table 6 . However, the interaction terms between household credit and 
Table 7. Result of quantile regression (interaction between business credit with institutions, household credit with institutions)

\begin{tabular}{lccccc}
\hline & $(1)$ & $(2)$ & $(3)$ & $(4)$ & $(5)$ \\
Variables & $\mathrm{q} 10$ & $\mathrm{q} 25$ & $\mathrm{q} 50$ & $\mathrm{q} 75$ & $\mathrm{q} 90$ \\
\hline Physical capital & $0.383^{* *}$ & $0.363^{* * *}$ & $0.359^{* * *}$ & $0.327^{* * *}$ & $0.338^{* *}$ \\
& $(0.148)$ & $(0.116)$ & $(0.102)$ & $(0.113)$ & $(0.153)$ \\
Population growth & -0.779 & -1.385 & $-1.621^{* * *}$ & $-1.296^{* *}$ & $-1.891^{* *}$ \\
& $(1.165)$ & $(0.957)$ & $(0.556)$ & $(0.595)$ & $(0.820)$ \\
Human capital & 6.13 & $7.30^{* *}$ & $7.97^{* * *}$ & $7.69 * * *$ & $8.21^{* * *}$ \\
& $(20.91)$ & $(3.315)$ & $(2.65)$ & $(2.74)$ & $(2.91)$ \\
Business credit (BC) & 0.0985 & 0.0516 & 0.0459 & 0.0552 & 0.0234 \\
& $(0.0760)$ & $(0.0643)$ & $(0.0386)$ & $(0.0394)$ & $(0.0603)$ \\
Household credit (HC) & -0.0261 & 0.0159 & 0.0758 & 0.0855 & 0.164 \\
& $(0.103)$ & $(0.0889)$ & $(0.0731)$ & $(0.0929)$ & $(0.121)$ \\
Institutions (INS) & 3.162 & $3.422^{*}$ & $4.250^{* *}$ & $4.528^{* *}$ & 4.624 \\
& $(2.324)$ & $(1.989)$ & $(1.831)$ & $(2.135)$ & $(3.138)$ \\
BC x INS & 0.0101 & 0.0073 & $0.0054^{* *}$ & $0.0077^{* *}$ & 0.0017 \\
& $(0.0137)$ & $(0.0105)$ & $(0.0024)$ & $(0.0033)$ & $(0.0128)$ \\
HC x INS & 0.00642 & -0.0300 & $-0.0335^{* * *}$ & $-0.0334^{* *}$ & $-0.0357^{* *}$ \\
& $(0.0209)$ & $(0.0183)$ & $(0.0114)$ & $(0.0157)$ & $(0.0178)$ \\
Constant & -61.68 & $-196.6 * *$ & $-200.1^{* * *}$ & $-181.3^{* * *}$ & $-201.6 * * *$ \\
& $(89.59)$ & $(77.20)$ & $(48.73)$ & $(49.37)$ & $(69.30)$ \\
Observations & 81 & 81 & 81 & 81 & 81 \\
\hline
\end{tabular}

Note: The dependent variable for the quantile regression is real GDP per capita. Figures in parentheses are standard errors. ${ }^{* * *}, * *$ and ${ }^{*}$ denote significance at $1 \%, 5 \%$ and $10 \%$ levels, respectively.

institutions are negative and significant at the 50th, 75th and 90th quantiles. Again, the results demonstrate household credit has a negative effect on economic performance even in the presence of good institutions. The findings are in line with Table 6 where the results reported contain the interaction between household credit and institutions. Therefore, the results remained similar even though two interaction terms are involved in the model specification.

\subsection{Robustness Checks}

We also carried out robustness checks to evaluate the sensitivity of the empirical findings to alternative estimation using Machado et al. (2011) robust standard error quantile regression. The empirical results are reported in Table 8 , which contains five models (in 50th quantile) with different control variables. Model (1) reports the basic model and the business credit is a significant determinant of economic performance. Model (2) includes all control variables in the specification and the results indicate that business credit is significant. In Model (3) we drop government expenditure that shows the highest $p$-value insignificant variable, the empirical results reveal that business 
Table 8. Robustness checks using quantile regression with robust standard error

\begin{tabular}{|c|c|c|c|c|c|}
\hline Variables & $\begin{array}{l}\text { Model (1) } \\
\text { q50 }\end{array}$ & $\begin{array}{l}\text { Model (2) } \\
\text { q50 }\end{array}$ & $\begin{array}{l}\text { Model (3) } \\
\text { q50 }\end{array}$ & $\begin{array}{c}\text { Model (4) } \\
\text { q50 }\end{array}$ & $\begin{array}{l}\text { Model (5) } \\
\text { q50 }\end{array}$ \\
\hline Physical capital & $\begin{array}{c}0.278^{* * *} \\
(0.094)\end{array}$ & $\begin{array}{c}0.303^{* *} \\
(0.137)\end{array}$ & $\begin{array}{c}0.291 * * \\
(0.125)\end{array}$ & $\begin{array}{c}0.313^{* *} \\
(0.139)\end{array}$ & $\begin{array}{c}0.189 * * * \\
(0.062)\end{array}$ \\
\hline Human capital & $\begin{array}{c}28.78^{* * *} \\
(9.48)\end{array}$ & $\begin{array}{l}22.01^{*} \\
(11.37)\end{array}$ & $\begin{array}{c}19.73 * * \\
(8.57)\end{array}$ & $\begin{array}{c}20.06 * * * \\
(6.211)\end{array}$ & $\begin{array}{c}21.09 * * * \\
(6.330)\end{array}$ \\
\hline Population growth & $\begin{array}{l}-0.07 \\
(0.30)\end{array}$ & $\begin{array}{l}-0.151 \\
(0.490)\end{array}$ & $\begin{array}{c}-0.171 \\
(0.721)\end{array}$ & $\begin{array}{l}-0.253 \\
(0.215)\end{array}$ & $\begin{array}{l}-0.246 \\
(0.202)\end{array}$ \\
\hline Business credit & $\begin{array}{c}0.117^{* * *} \\
(0.041)\end{array}$ & $\begin{array}{c}0.268 \\
(0.030)\end{array}$ & $\begin{array}{c}0.448^{* *} \\
(0.189)\end{array}$ & $\begin{array}{c}0.531^{* *} \\
(0.236)\end{array}$ & $\begin{array}{c}-0.127^{* * *} \\
(0.027)\end{array}$ \\
\hline Household credit & $\begin{array}{c}0.083 \\
(0.077)\end{array}$ & $\begin{array}{c}0.091 \\
(0.055)\end{array}$ & $\begin{array}{c}0.112 \\
(0.078)\end{array}$ & $\begin{array}{c}0.140 \\
(0.134)\end{array}$ & $\begin{array}{c}0.050 \\
(0.051)\end{array}$ \\
\hline Government expenditure & - & $\begin{array}{l}-0.029 \\
(0.031)\end{array}$ & - & - & - \\
\hline FDI & - & $\begin{array}{c}0.073 \\
(0.069)\end{array}$ & $\begin{array}{c}0.056 \\
(0.098)\end{array}$ & - & - \\
\hline Trade openness & - & $\begin{array}{c}0.283^{* * *} \\
(0.099)\end{array}$ & $\begin{array}{c}0.205 * * \\
(0.085)\end{array}$ & $\begin{array}{c}0.216^{* * *} \\
(0.073)\end{array}$ & - \\
\hline Inflation & - & $\begin{array}{l}-0.710 \\
(0.428)\end{array}$ & $\begin{array}{l}-0.768 \\
(0.620)\end{array}$ & $\begin{array}{c}-0.705^{* *} \\
(0.306)\end{array}$ & - \\
\hline Institutions & - & $\begin{array}{c}0.509 * * \\
(0.226)\end{array}$ & $\begin{array}{c}0.903 * * * \\
(0.157)\end{array}$ & $\begin{array}{c}0.835^{* * *} \\
(0.291)\end{array}$ & $\begin{array}{c}2.048^{* * *} \\
(0.315)\end{array}$ \\
\hline Business credit $\mathrm{x}$ institutions & - & - & - & - & $\begin{array}{c}2.145^{* *} \\
(1.031)\end{array}$ \\
\hline Constant & $\begin{array}{c}-105.25^{* * *} \\
(39.91)\end{array}$ & $\begin{array}{l}-89.52^{*} \\
(48.38)\end{array}$ & $\begin{array}{l}-79.34 \\
(68.67)\end{array}$ & $\begin{array}{c}-115.0 * * * \\
(26.09)\end{array}$ & $\begin{array}{c}-125.44 * * * \\
(26.62)\end{array}$ \\
\hline Pseudo $\mathrm{R}^{2}$ & 0.9125 & 0.9559 & 0.9555 & 0.9543 & 0.9367 \\
\hline Observations & 81 & 81 & 81 & 81 & 81 \\
\hline
\end{tabular}

Note: The dependent variable for the quantile regression is real GDP per capita. Figures in parentheses are standard errors. $* * *, * *$ and $*$ denote significance at $1 \%, 5 \%$ and $10 \%$ levels, respectively.

credit appears to be significant, but not household credit. In Model (4) we drop another insignificant variable, namely, FDI, business credit is still significant whereas household credit is insignificant. Lastly, a similar pattern arises when comparing the interaction term between business credit and institutions in Model (5), where the interaction term is significant and the finding is in line with Table 5. We also use the World Governance Indicators (WGI) from World Bank as another measurement of institutions. The empirical results are similar with the ICRG indicators where the interaction term between business credit and institutions is statistically significant, but not with household credit. However, the results are not reported to save space but are available upon request. Thus, the empirical findings are robust to the alternative quantile regression estimation method, different control variables and alternative institutions indicator. 


\section{Conclusions}

This study examines whether credit to both businesses and households has a significant impact on economic performance in Malaysia, an emerging market where the ease of getting credit is ranked number one across the developing countries. The quarterly time series cover the sample period from 1999: Q4 to 2019: Q4, and the empirical analysis utilises quantile regression. We pay particular attention as to whether too much credit impedes or harms economic performance where we distinguish business credit from household credit. If business credit outperforms household credit in promoting economic performance, then the credit policy should give priority to businesses rather than households.

The empirical findings reveal that total credit is a statistically significant determinant of economic performance in Malaysia. However, when we divided credit into business credit and household credit, business credit outperforms household credit. This finding demonstrates not only more credit enhances economic performance, but the effect is contingent on the types of credit. Business credit is more productive and can be channelled to investments that need capital to expand their businesses, which further stimulates economic performance via the multiplier effect. Therefore, policy makers should encourage business credit in the market by avoiding the rationing of credit to businesses and increasing the portion of bank loans to business investments. The coefficients of business credit either with or without the interaction term with institutions are greater than household credit. Household credit, on the other hand, is insignificant in promoting economic performance and the effect on economic performance is lower compared to business credit.

The marginal effect in all quantiles is evaluated at the mean, minimum and maximum value of institutions based on the computed new standard error. Overall, business credit shows a significant marginal effect especially at the mean value of institutions, but not at the minimum level. However, too much credit also has a tendency to reduce economic performance if institutions are weak. This is because institutions are a deeply rooted factor and change gradually and may not be able to cater for economic uncertainty. On the other hand, the marginal effects of household credit are insignificant regardless at the mean, minimum or maximum levels of institutions. The results also suggest that there is no non-linear relationship between credit and economic performance in Malaysia, and illustrate how the magnitudes of the business credit and household credit vary over quantiles.

\section{References}

Aghion, P., Angeletos, G.-M., Banerjee, A., \& Manova, K. (2010). Volatility and growth: Credit constraints and the composition of investment. Journal of Monetary Economics, 57(3), 246265. https://doi.org/10.1016/j.jmoneco.2010.02.005

Ahmed, F., Kousar, S., Pervaiz, A., \& Shabbir, A. (2021). Do institutional quality and financial development affect sustainable economic growth? Evidence from South Asian countries. Borsa Istanbul Review. Advance online publication. https://doi.org/10.1016/j.bir.2021.03.005

Alfaro, L., Chanda, A., Kalemli-Ozcan, S., \& Sayek, S. (2004). FDI and economic growth: The role of local financial markets. Journal of International Economics, 64(1), 89-112. https://doi. org/10.1016/S0022-1996(03)00081-3 
Arcand, J.-L., Berkes, E., \& Panizza, U. (2012). Too much finance? (IMF Working Paper 12/161). https://www.imf.org/external/pubs/ft/wp/2012/wp12161.pdf

Azman-Saini, W.N.W., Law, S.H., \& Halim, A. (2010). FDI and growth: New evidence on the role of financial markets. Economic Letters, 107(2), 211-213.

Bahadir, B., \& Valev, N. (2017) Catching up or drifting apart: Convergence of household and business credit in Europe. International Review of Economics \& Finance, 47, 101-114. https://doi.org/10.1016/j.iref.2016.10.006

Baharumshah, A.Z., \& Almasaied, S.W. (2009). Foreign direct investment and economic growth in Malaysia: Interactions with human capital and financial deepening. Emerging Markets Finance and Trade, 45(1), 90-102. https://doi.org/10.2753/REE1540-496X450106

Baharumshah, A.Z., Slesman, L., \& Wohar, M.E. (2016). Inflation, inflation uncertainty, and economic growth in emerging and developing countries: Panel data evidence. Economic Systems, 40(4), 638-657. https://doi.org/10.1016/j.ecosys.2016.02.009

Balli, H.O., \& Sorensen, B.E. (2013). Interactions effects in econometrics. Empirical Economics, 45, 583-603. https://doi.org/10.1007/s00181-012-0604-2

Barrail, Z. (2020). Business cycle implications of rising household credit market participation in emerging countries. Journal of Economic Dynamics and Control, 116, Article 103917. https:// doi.org/10.1016/j.jedc.2020.103917

Beck, T., Buyukkarabacak, B., Rioja, F., \& Valev, N. (2012). Who gets the credit? And does it matter? Household vs. firm lending across countries. B.E. Journal of Macroeconomics, 12(1), 1-46. https://doi.org/10.1515/1935-1690.2262

Beck, T., Demirguc-Kunt, A., Maksimovic, V. (2005). Financial and legal constraints to growth: Does firm size matter? Journal of Finance, 60(1), 137-177. https://doi.org/10.1111/j.15406261.2005.00727.x

Bezemer, D., \& Zhang, L. (2019. Credit composition and the severity of post-crisis recessions. Journal of Financial Stability, 42, 52-66. https://doi.org/10.1016/j.jfs.2019.05.010

Boateng, E., Agbola, F.W., Mahmood, A. (2021) Foreign aid volatility and economic growth in SubSaharan Africa: Does institutional quality matter? Economic Modelling, 96, 111-127. https:// doi.org/10.1016/j.econmod.2020.12.032

Brambor, T., Clark, W.R., \& Golder, M. (2006). Understanding interaction models: Improving empirical analyses. Political Analysis, 14(1), 63-82.

Buchinsky, M. (1995). Estimating the asymptotic covariance matrix for quantile regression models a Monte Carlo study. Journal of Econometrics, 68(2), 303-338. https://doi.org/10.1016/03044076(94)01652-G

Buyukkarabacak, B., \& Valev, N.T. (2010). The role of household and business credit in banking crises. Journal of Banking and Finance, 34(6), 1247-1256. https://doi.org/10.1016/j. jbankfin.2009.11.022

Cecchetti, S.G., \& Kharroubi, E. (2012). Reassessing the impact of finance on growth (BIS Working Papers No. 381), Bank of International Settlements.

Corradini, C. (2020). Local institutional quality and economic growth: A panel-VAR analysis of Italian NUTS-3 regions. Economics Letters, 198, Article 109659. https://doi.org/10.1016/j. econlet.2020.109659

Demetriades, P., \& Law, S.H. (2006). Finance, institutions and economic development. International Journal of Finance \& Economics, 11(3), 245-260. https://doi.org/10.1002/ijfe.296

De Gregorio, J. (1996). Borrowing constraints, human capital accumulation and growth. Journal of Monetary Economics, 37(1), 49-71. https://doi.org/10.1016/0304-3932(95)01234-6

Eggoh, J.C., \& Khan, M. (2014). On the nonlinear relationship between inflation and economic growth. Research in Economics, 68(2), 133-143. https://doi.org/10.1016/j.rie.2014.01.001

Ekinci, M.F., \& Omay, T. (2020). Current account and credit growth: The role of household credit and financial depth. North American Journal of Economics and Finance, 54, Article 101244. https://doi.org/10.1016/j.najef.2020.101244 
Elekdag, S., \& Han, F. (2015). What drives credit growth in emerging Asia? Journal of Asian Economics, 38, 1-13. https://doi.org/10.1016/j.asieco.2015.03.001

Goh, S.K., Sam, C.Y, \& McNown, R. (2017). Re-examining foreign direct investment, exports, and economic growth in Asian economies using a bootstrap ARDL test for cointegration. Journal of Asian Economics, 51, 12-22. https://doi.org/10.1016/j.asieco.2017.06.001

Hajamini, M., \& Falahi, M.A. (2018). Economic growth and government size in developed European countries: A panel threshold approach. Economic Analysis and Policy, 58, 1-13. https:// doi.org/10.1016/j.eap.2017.12.002

Hall, R.E., \& Jones, C.I. (1999). Why do some countries produce so much more output per worker than others? Quarterly Journal of Economics, 114(1), 83-116.

Hassan, M.K., Sanchez, B., Yu, J.S. (2011). Financial development and economic growth: New evidence from panel data. Quarterly Review of Economics and Finance, 51(1), 88-104. https://doi.org/10.1016/j.qref.2010.09.001

Hung, F.-S. (2009). Explaining the nonlinear effects of financial development on economic growth. Journal of Economics, 97(1), 41-65. https://doi.org/10.1007/s00712-008-0057-4

Hung, F.-S., \& Cothren, R. (2002). Credit market development and economic growth. Journal of Economics and Business, 54(2), 219-237. https://doi.org/10.1016/S0148-6195(01)00063-7

Jappelli, T., \& Pagano, M. (1994). Saving, growth, and liquidity constraints. Quarterly Journal of Economics, 109(1), 83-109. https://doi.org/10.2307/2118429

Kar, M., Nazlioglu, S., \& Agir, H. (2011). Financial development and economic growth nexus in the MENA countries: Bootstrap panel granger causality analysis. Economic Modelling, 28(1-2), 685-693. https://doi.org/10.1016/j.econmod.2010.05.015

Knack, S., \& Keefer. P. (1995). Institutions and economic performance: Cross-country tests using alternative institutional measures. Economics and Politics, 7(3), 207-227. https://doi.org/ 10.1111/j.1468-0343.1995.tb00111.x

Koenker, R., \& Bassett, G. (1978). Regression quantiles. Econometrica, 46(1), 33-50. https://doi. org $/ 10.2307 / 1913643$

Koenker, R., \& Hallock, K.F. (2001). Quantile regression. Journal of Economic Perspectives 15(4), 143-156. https://doi.org/10.1257/jep.15.4.143

Laeven, L. (2002). Financial constraints on investments and credit policy in Korea. Journal of Asian Economics, 13, 251-269. https://doi.org/10.1016/S1049-0078(02)00111-2

Law, S.H., \& Singh, N. (2014). Does too much finance harm economic growth? Journal of Banking \& Finance, 41, 36-44. https://doi.org/10.1016/j.jbankfin.2013.12.020

Law, S.H., \& Azman-Saini, W.N.W. (2012). Institutional quality, governance and financial development. Economics of Governance, 13(3), 217-236. https://doi.org/10.1007/s10101-0120112-z

Law, S.H., Azman-Saini, W.N.W., \& Ibrahim, M.H. (2013). Institutional quality thresholds and finance-growth nexus. Journal of Banking and Finance 37(12), 5373-5381. https://doi. org/10.1016/j.jbankfin.2013.03.011

Levine, R., Loayze, N., \& Beck, T. (2000). Financial intermediation and growth: Causality and causes. Journal of Monetary Economics, 46(1), 31-77. https://doi.org/10.1016/S03043932(00)00017-9

Ma, S., Wu, X., \& Gan, L. (2019). Credit accessibility, institutional deficiency and entrepreneurship in China. China Economic Review, 54, 160-175. https://doi.org/10.1016/j.chieco.2018.10.015

Machado, J.A.F., Parente, P.M.D.C., \& Santos Silva, J.M.C. (2011). QREG2: Stata module to perform quantile regression with robust and clustered standard errors. Statistical Software Components S457369, Boston College Department of Economics.

Montalbano, P. (2011). Trade openness and developing countries' vulnerability: Concepts, misconceptions, and directions for research. World Development, 39(9), 1489-1502. https:// doi.org/10.1016/j.worlddev.2011.02.009 
Musila, J.W., \& Yiheyis, Z. (2015). The impact of trade openness on growth: The case of Kenya. Journal of Policy Modelling, 37(2), 342-354. https://doi.org/10.1016/j.jpolmod.2014.12.001

Mustafa, G., Rizov, M., \& Kernohan, D. (2017). Growth, human development, and trade: The Asian experience. Economic Modelling, 61, 93-101. https://doi.org/10.1016/j.econmod. 2016.12.007

Pegkas, P. (2015). The impact of FDI on economic growth in Eurozone countries. Journal of Economic Asymmetrics, 12(2), 124-132. https://doi.org/10.1016/j.jeca.2015.05.001

Rahaman, M.M. (2011). Access to financing and firm growth. Journal of Banking \& Finance, 35(3), 709-723. https://doi.org/10.1016/j.jbankfin.2010.09.005

Rodrik, D., Subramanian, A., \& Trebbi, F. (2004). Institutions rule: The primacy of institutions over geography and integration in economic development. Journal of Economic Growth, 9, 131165. https://doi.org/10.1023/B:JOEG.0000031425.72248.85

Sassi, S., \& Gasmi, A. (2014). The effect of enterprise and household credit on economic growth: New evidence from European union countries. Journal of Macroeconomics, 39(Part A), 226231. https://doi.org/10.1016/j.jmacro.2013.12.001

Sim, S.-G., \& Lee, S. (2020). The cyclical behavior of household and corporate credit in emerging economies. Emerging Markets Review, 45, Article 100724. https://doi.org/10.1016/j. ememar.2020.100724

Sukmana, R., \& Ibrahim, M.H. (2018). Financial access and inequality: A quantile assessment. International Journal of Economics and Management, 12(2), 551-557.

Vinayagathasan, T. (2013). Inflation and economic growth: A dynamic panel threshold analysis for Asian economies. Journal of Asian Economics, 26, 31-41. https://doi.org/10.1016/j. asieco.2013.04.001

Wu, S.Y., Tang, J.H., \& Lin, E.S. (2010). The impact of government expenditure on economic growth: How sensitive to the level of development. Journal of Policy Modeling, 32(6), 804817. https://doi.org/10.1016/j.jpolmod.2010.05.011

World Bank. (2016). World Development Indicators. 